\title{
Assessment of Knowledge, Attitude and Practice of Complementary and Alternative Medicine among Elderly People Attending Health Insurance Outpatient Clinics in Ismailia Governorate
}

Eman E. Khattab ${ }^{1} *$ Mohamed H. Shehata ${ }^{2}$ Enayat M. Soltan, ${ }^{2}$

${ }^{1}$ Ministry of Health, Ismailia Governorate, El Sheikh Zayed Family Health Center.

${ }^{2}$ Family Medicine department, Faculty of Medicine, Suez Canal University.

\section{Abstract:}

Background: Recent surveys concluded that the elderly people are using complementary and alternative medicine (CAM) frequently. Use of CAM among older patients is considered significant challenge. Preventing adverse reactions and drug interactions associated with CAM use is complicated by the fact that only less than $50 \%$ of older patients disclose CAM use to their treating physicians. That is why it is essential for family physicians to explore knowledge, attitude and practice of elderly people towards CAM. Objective: This study aimed to assess knowledge, attitude and practices of elderly people towards complementary and alternative medicine. Methods: This is a cross sectional descriptive study; it was conducted in March and April 2016, in health insurance outpatients clinics in Ismailia governorate. Sample size was 150 elderly people allocated consecutively over the two months. Results: About $84 \%$ of elderly have some knowledge regarding CAM; herbs were known by (75\%) of the selected sample and their source of knowledge was mainly the media $(56 \%)$ followed by their family and friends. The reported success rate of CAM to relieve symptoms of the study population was (54.7\%). Regarding beliefs of the study participants about the use of CAM; $(76 \%)$ believe in CAM safety, (58.7\%) believe that CAM is effective, while (54.7\%) do not believe that CAM are better than drugs , $64 \%)$ perceive that they need health education about CAM. Conclusion: The current study concludes that CAM use is highly prevalent among people. However, there is a demand for better and consistent information about herbal medicine regarding effectiveness and safety. Keywords: Complementary, medicine, alternative medicine, elderly, knowledge, attitude, practice, herbal medicine.

Introduction: Elderly people are always some time in their past life.

willing to search ways which improve their health and found to use complementary and alternative medicine (CAM) more often than other age groups. ${ }^{(1)}$ In Egypt, a family-based study was carried out in Bir El Abd district, North Sinai Governorate to study complementary and alternative practices in Bedouin revealed that $38 \%$ of the studied population had used CAM at Herbal/nutritional therapies were the most frequently used (37 \%) as CAM therapy, followed by cupping $(36 \%){ }^{(2)}$

There are many definitions for CAM, according to The National Center for Complementary and Alternative Medicine in United States (NCCAM), CAM is defined as a group of diverse medical and healthcare systems, practices, and products that are not

Corresponding author: Email: om.muslim@ hotmail.com 
generally considered part of conventional medicine ${ }^{(3)}$. The World Health Organization (WHO) defines traditional medicine as those including diverse health practices, approaches, knowledge and beliefs incorporating plant, animal and/or mineral based medicines, spiritual therapies, manual techniques and exercises applied singularly or in combination to maintain wellbeing, as well as to treat, diagnose or prevent illness. ${ }^{(4)}$

The CAM services are often used alongside (and in addition to) conventional medical treatments. So, a vast informal and silent healthcare sector exists in all countries, and no comprehensive picture of this sector exists as yet in any country. ${ }^{(5)}$ Data on the current patterns of use and effectiveness of multiple CAM treatments being used alone and in combination are inadequate. CAM is used by people for the management of chronic conditions that are expensive to society, such as arthritis and chronic pain, and more life-threatening diseases such as heart diseases and cancer ${ }^{(6)}$ Nearly half the population in many developed countries regularly use some form of CAM (United States represents $42 \%,{ }^{(7)}$ Australia represents $48 \%,{ }^{(8)}$ France represents $49 \%,{ }^{(9)}$ and Canada represents $70 \%$. A considerable use exists in many developing countries (Colombia 40\%; Chile 71\%; and up to $80 \%$ in African countries). ${ }^{(10,4)}$

There are numerous reasons why older consumers access CAM for their health needs. These include disillusionment with conventional medicine that offers no firm answers, dissatisfaction with conventional practitioners who may exhibit poor communication, lack of empathy, and have so limited time, desire for simplicity as CAM preparations are perceived to be "simple" without complex directions, warnings and labels, perception that natural preparations promote optimum health, more compatible with health' and, ready access via Internet, health food shops, free call hot-lines, mail-order, free home-delivery, party-plan and multilevel marketing, enticing advertising that encourages a CAMs trial, alternative lifestyles and 'keep fighting the disease and peer pressure fashion'. Postpone age-related deterioration and mortality 
and desire for autonomy over healthcare decisions. ${ }^{(11-15)}$

Role of family physician is crucial in handling the above mentioned problems of CAM use among the practice population. Such role might be in making patients more informed towards their choice about CAM. Specifically physicians can protect, permit, promote, and partner with patients about CAM practices as appropriate. $^{(16)}$ As there are limited studies in this area of Medicine in Egypt, the question arising is: What are the prevalence, socio-cultural and personal factors (knowledge, beliefs, attitudes, motivations) underlying a person's decision to use CAM? Hence, the present work will assess knowledge, attitude and practice of the elderly people attending health insurance outpatient clinics in Ismailia towards CAM.

Methods: This is a cross sectional descriptive study; it was conducted in March and April 2016 at health insurance outpatient clinics in Ismailia governorate. The sample size was calculated according to the following equation $;^{(17)} \mathbf{n}=(\mathbf{Z} \boldsymbol{\alpha})^{\mathbf{2}}(\mathbf{p}-\mathbf{1}) / \mathbf{d}^{\mathbf{2}}$ Where: $\mathrm{n}=$ estimated sample size. $\mathrm{Z} \alpha$ at $5 \%$ level of significance $=1.96 . \mathrm{d}=$ level of precision and is estimated to be $0.05 \mathrm{p}$ $=$ prevalence rate of CAM use in two previous studies in the region that was $40 \% .^{(2,18)}$ So,

$\mathrm{n}=1.96 * 1.96)(0.40 * 0.60) /(0.40 * 0.10 * 1.96=150$ elders.

Sample size was 150 elderly people allocated consecutively over the two months.

All Patients aged 60 years and above who attended health insurance outpatient clinics in Ismailia governorate who satisfied the inclusion criteria were recruited. Elders with impaired cognitive functions that interfere with the reliability of the given data were excluded .Data were collected using a pre-designed questionnaire including the following four sections:

1. Socio-demographic data including: age, sex, residence, education, occupation before retirement, income, current medical condition.

2. Participant background knowledge of CAM and his/her sources of information.

3. Practice of CAM: enquires about use of CAM of the participant and the medical condition helshe used CAM.

4. The fourth section is concerned to explore the beliefs of the respondents towards CAM. 
The participants were invited to in depth interview with the researcher to explore their knowledge, attitude and practice towards CAM.

Ethical approval: The protocol was done after approval from the faculty studies Committee, the Research Committee as well as the Research Ethics Committee. Informed consent was obtained from the participants after explaining the objectives of the research. Confidentiality of data was maintained and the participants were free to accept or not to participate in the research.

Statistical analysis: The collected data were analyzed using Statistical Package for Social Sciences -SPSS 20.0 (SPSS Ltd, Chicago, USA). Descriptive statistics: qualitative data were presented in frequencies and percentages and quantitative data were presented in median (interquartile range), and mean ranks.

Results: This study was conducted on 150 elderly people in health insurance outpatient clinics, Males constituted $(52.7 \%)$ of the sample and the majority of the studied population $(68 \%)$ live in urban. $39 \%$ of the studied population have an intermediate educational level and $(56.7 \%)$ of the sample has perceived their income as inadequate. More than three-quarters $(84 \%)$ of elderly have knowledge regarding complementary and alternative medicine, only one type of CAM (herbs) was known by (75\%) of the selected sample. Figure (1) shows types of complementary and alternative medicine used. It shows that; herbs are the most common type used $(36.7 \%)$ followed by cupping (15.3\%) then honey and honey products $(8 \%)$.

Figure (2) shows methods of using complementary and alternative medicine. It is evident that; complementary medicine was used with treatment in $45.3 \%$ of the study population and alone in $26 \%$. About one third of the study population used CAM based on advice from a family-member while (19.3\%) had an advice from a friend and only $10.7 \%$ had their treating physicians recommended using CAM (Figure-3). Figure (4) shows consequences of using complementary and alternative medicine. It shows that; more than half of the symptoms $54.7 \%$ were relieved when using CAM, while only $7.3 \%$ suffered from some complications. About $28.7 \%$ used CAM 
because they believed that CAM is safe, $19.3 \%$ because CAM is inexpensive (Figure-5).

Discussion: The aim of this study was to assess knowledge, attitude and practice of the elderly people regarding complementary and alternative medicine which may help in improvement of the quality of medical service provided for those patients. The expected probability of CAM use among our study population is significantly affected by the level of education $(\mathrm{P}<0.05)$. However, other socio-economic factors (residence, income and work) did not show an effect over the CAM knowledge, practice and attitude. These results were in partial agreement with the results of a study conducted in United States of America (USA) that reported that rural residence, age, income, education, and health insurance were unrelated to CAM use. ${ }^{(19)}$ The role of socio-demographic variables is considered to be important as predictors of CAM use. The importance of each variable will vary from country to another mainly due to cultural differences.

About $50 \%$ and $64 \%$ of the study population agreed that there is need for
CAM clinics in governmental hospitals and the need for health education about CAM respectively. These results were slightly lower than those reported by AlFaris et al.(2000) who recorded that $86.9 \%$ of participants agreed on the need for clinics for CAM practice ${ }^{(20)}$. In terms of safety and efficacy of CAM; the results were similar to those reported by Al-Faris et al(2008). ${ }^{(21)}$

As showed in this study, CAM practices were commonly used for chronic morbidities. The situation among Americans and Indians was almost similar to this studies' results as CAM was used to treat neck pain, joint pain or stiffness, back pain, /diabetes mellitus, hypertension, arthritis and anxiety or depression. ${ }^{(22,23)}$ Our study showed that the use of CAM therapies involved a wide spectrum of medical problems ranging from simple, transient and self-limited up to serious, long term disabling and terminal conditions.

The relatively high use of CAM can be explained by the background of existing trans-cultural view towards use of CAM practices before seeking medical advice from medical health care 
providers or even after. Also, Patients in rural areas (like our study population) face a variety of unmet needs due to less available resources to choose from, poverty, perceived reliability of these therapies based on religious or family traditions and the availability of such practices. All of these factors may contribute to the use of CAM therapies. Also, Physicians' attitudes towards CAM and poor patient-doctor communication may be other reasons why patients use CAM more and even without informing the treating physician.

Herbal therapies are one of the most frequently used CAM practices. According to the World Health Organization (WHO), more than threequarters of the world's population trust in traditional medicine, especially herbs. $^{(24)}$ Our results $(36.7 \%)$ were higher than those reported from two separate studies conducted in the United States which reported that $(20 \%)$ and $(24 \%)$ of participants had used medicinal herbs. ${ }^{(25)}$ More than two-thirds of our studied population; who used CAM (76\%) perceived it as a beneficial treatment modality and used it widely in different medical problems. Similar result $(75 \%)$ was reported by researchers in Japan. ${ }^{(26)}$

All results obtained in our study and all other studies can show the need to make the physician as a source of information. Also, being only source of information is inadequate but to be evidence-based as reported recently by American Academy of Family Practitioners (AAFP). ${ }^{(27)}$ A good doctorpatient relationship will be one of the most important factors in this issue, where in absence of such relationship, the patient may deny such CAM rather than informing his physician.

Our study population only represents Ismailia governorate so the results cannot be generalized to all Egyptian governorates that have different cultures, habits and beliefs. Participants were not randomly selected so a consecutive sample was recruited with the application of the inclusion and exclusion criteria until the sample size was fulfilled. Open access to needed papers was restricted by payment, so availability of relevant papers was limited. 
Conclusions: There is high prevalence and high interest in CAM practices among elderly people. Mass media, relatives and friends are the main sources of knowledge, and there is a positive attitude towards CAM, generally. However, most participants were reluctant to share CAM information with their physicians.

Declaration: There was no conflict of interest and there were no funding agencies

\section{References:}

1. Moses G. Complementary and alternative medicine use in the elderly. 34: 195e200. J Pharm Pract Res. 2005;35:63-68.

2. Nahed A. El-Dahshan, Mosleh A. Ismail, Ahmed S. Metwally. Studying complementary and alternative practices in Bedouin Community: Family based study, North Sinai, Egypt. Med. J. Cairo Univ., Vol. 83, No. 2, June 2015: 139-148.

3. National Center of Complementary and Alternative Medicine (NCCAM). Complementary and Alternative Medicine. What People aged 50 and older discuss with their health care providers. AARP and NCCAM Survey Report. U.S. Department of Health and Human Services, National Institute of Health; April 2011.

4. WHO. Proposed working definition of an older person in Africa for the MDS Project,2002.

5. Bodeker G. Planning for costeffective traditional health services. In: Traditional Medicine. Better Science, Policy and Services for Health Development. Proceedings of a WHO International Symposium, Awaji Island, Japan 11-13 September 2000 Kobe, Japan: WHO Kobe Centre; 2001:31-70.

6. Wootton J, Sparber A. Surveys of complementary and alternative medicine: Part IV. Use of alternative and complementary therapies for rheumatologic and other diseases. J Altern Complement Med,Dec 2001;7(6):715-721.

7. Eisenberg D, Davis B, Ettner L, Appel S, Wilkey S, van Rompay M, et al. Trends in alternative medicine use in the United States, 1990-1997: 
results of a follow-up national survey. JAMA, 1998; 280(18): 1569-75.

8. MacLennan A, Wilson D. Taylor A.. Prevalence and cost of alternative medicine in Australia. The Lancet,1996;347(9001):569-573.

9. Fisher P. Ward A. Complementary medicine in Europe. BMJ: British Medical Journal, 1994 Jul 9;309(6947):107-11.

10. Bannerman R, Burton J, Ch'en W. Traditional Medicine and Health Care Coverage. Geneva, Switzerland: World Health Organization; 1983.

11. Cherniak P, Cherniak N. Alternative medicine for the elderly. Berlin: Springer; 2003..

12. Spencer J, JacobsJ, J. Complementary and alternative medicine. An evidence based approach. 2nd edition. St Louis Missouri. Mosby 2003.

13. Cupp J, Tracy T. Forensic science: Dietary supplements: Toxicology and clinical pharmacology. Totowa,New Jersey: Humana Press; 2003.
14. Cassileth B, Deng G. Complementary and alternative therapies for cancer.Oncologist 2004; 9: 80-9

15. Thorne S, Paterson B, Russell C, Schultz

A.

Complementary/alternative medicine in chronic illness as informed selfcare decision-making. Int $\mathbf{J}$ Nurs Stud 2002; 39: 671-83.

16. Jonas W. Complementary and alternative medicine. In, South-Paul J, Matheny S, Lewis E. Current diagnosis and management in family medicine, $2^{\text {nd }}$ edition. 2008 .

17. Elolemy A,Albedah A. Public knowledge, attitude and practice of complementary and alternative medicine in Riyadh region, Saudi Arabia. Oman Med J2012; 27(1): 20-26.

18. Shalaby S, Mabrouk N. Complementary and alternative medicine Use among children in Ismailia - Egypt: Community based study. JASMR 2009; 4 (2):171-180.

19. Kaboli P, Doebbeling B, Saag K, Rosenthal G. Use of complementary and alternative medicine by older patients with arthritis: a 
population-based study. Arthritis

Care \& Research,2001; 45(4): 398403.

20. Al-Faris E. The pattern of alternative medicine use among patients attending health centres in a military community in Riyadh. Journal of Family and Community Medicine2000; 7(2)-17.

21. Al-Faris E, Al-Rowais N, Mohamed A , Al-Rukban M , Al-Kurdi A , AlNoor M, et al. Prevalence and pattern of alternative medicine use: The results a household survey. Ann Saudi Med 2008 Jan-Feb ;28(1):410.

22. Barnes J, Andersen L, Phillipson J. Herbal medicines. A guide for healthcare professionals. 2nd ed. London: Pharmaceutical Press; 2002.

23. SinghV, Raidoo D., Harries C. The prevalence, patterns of usage and people's attitude towards complementary and alternative medicine (CAM) among the Indian community in Chatsworth, South
Africa. BMC Complementary and Alternative Medicine,2004 Feb $4 ; 4: 3$.

24. World Health Organization(WHO) Traditional medicine-growing needs and potential. WHO Policy Perspectives Geneva, Med. 2002; 2: 1,6 .

25. Wheaton A, Blanck H, Gizlice Z, Reyes M. Medicinal herb use in a population-based survey of adults: Prevalence and frequency of use, reasons for use, and use among their children. Annals of epidemiology 2005;15(9):678-85.

26. Hori S, Mihaylov L, Vasconcelos J McCoubrie M. Complementary and Alternative Medicine. The official journal of the International Society for Complementary Medicine Research (ISCMR)2008;8:14.

27. Tascilar M, de Jong F, Verweij J, Mathijssen R. Complementary and alternative medicine during cancer treatment: beyond innocence. Oncologist. 2006;11(7):732-41. 


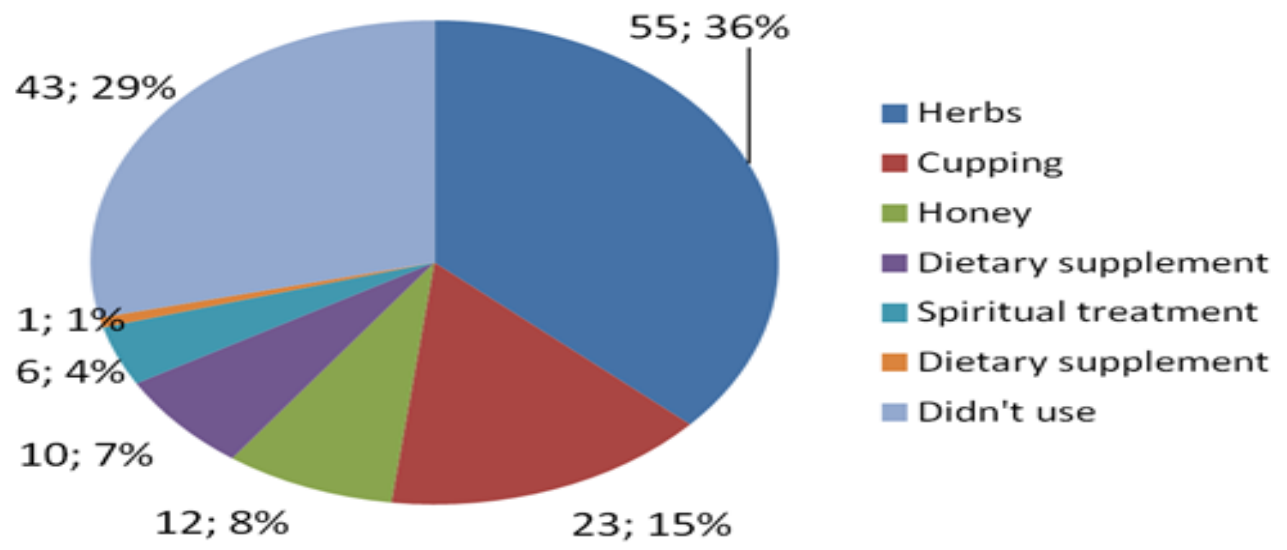

Figure1: Type of complementary and alternative medicine used $(n=150)$

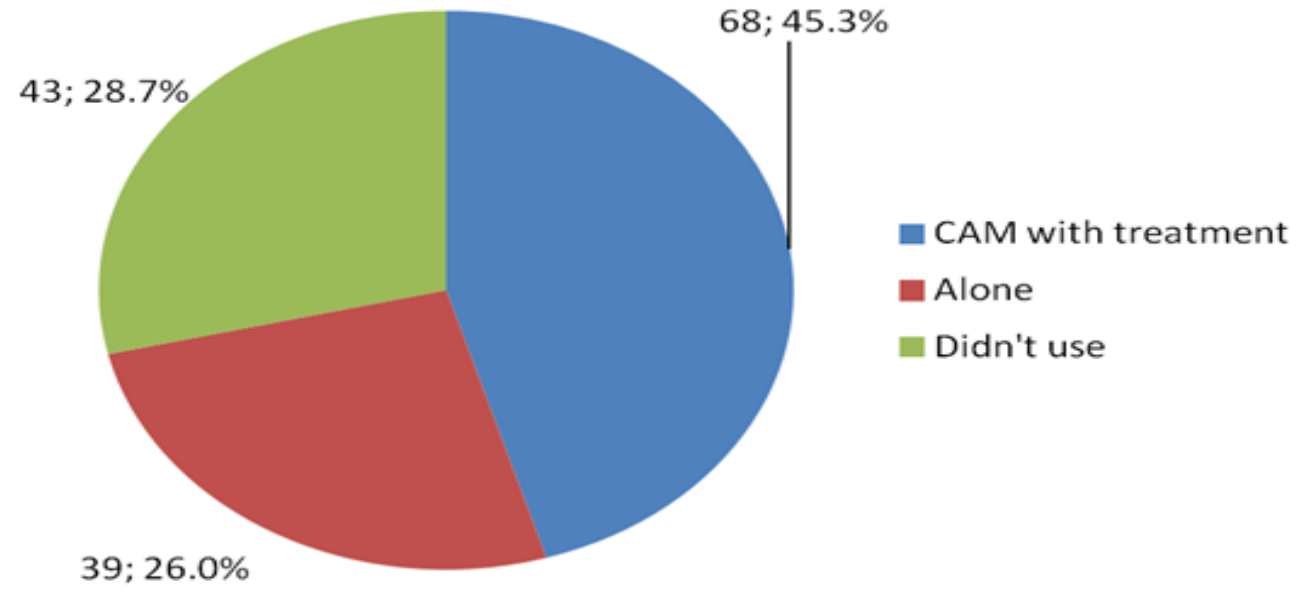

Figure 2: How complementary medicine was used $(n=150)$ 


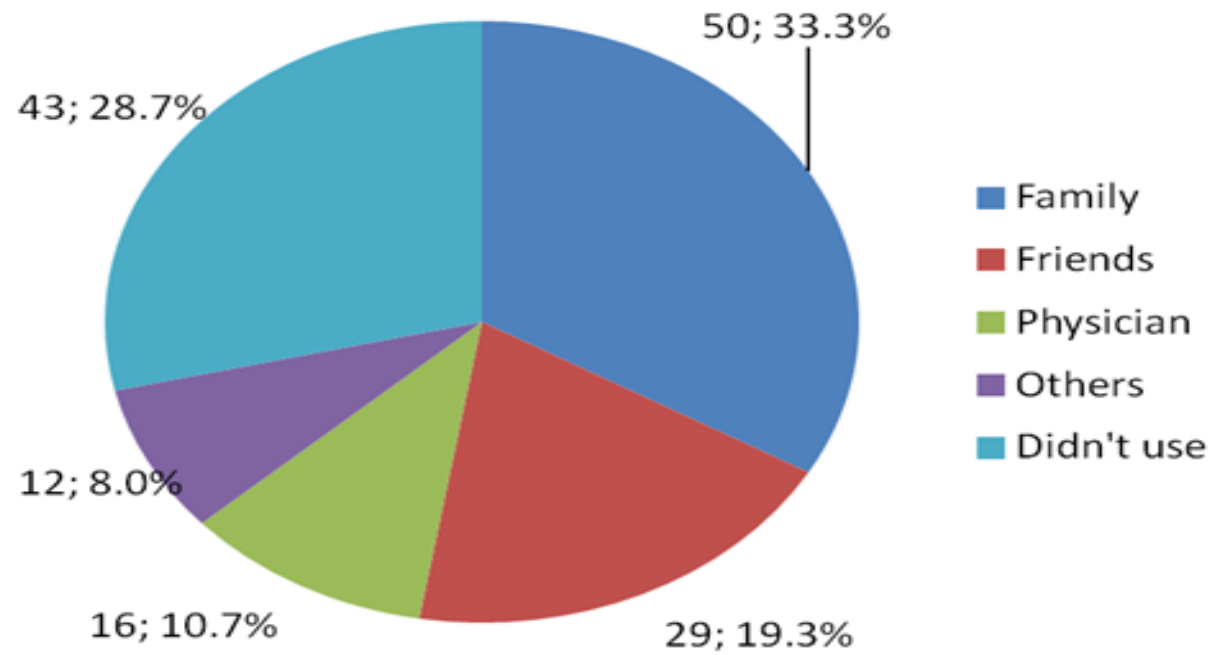

Figure 3: Person who recommended this treatment $(n=150)$

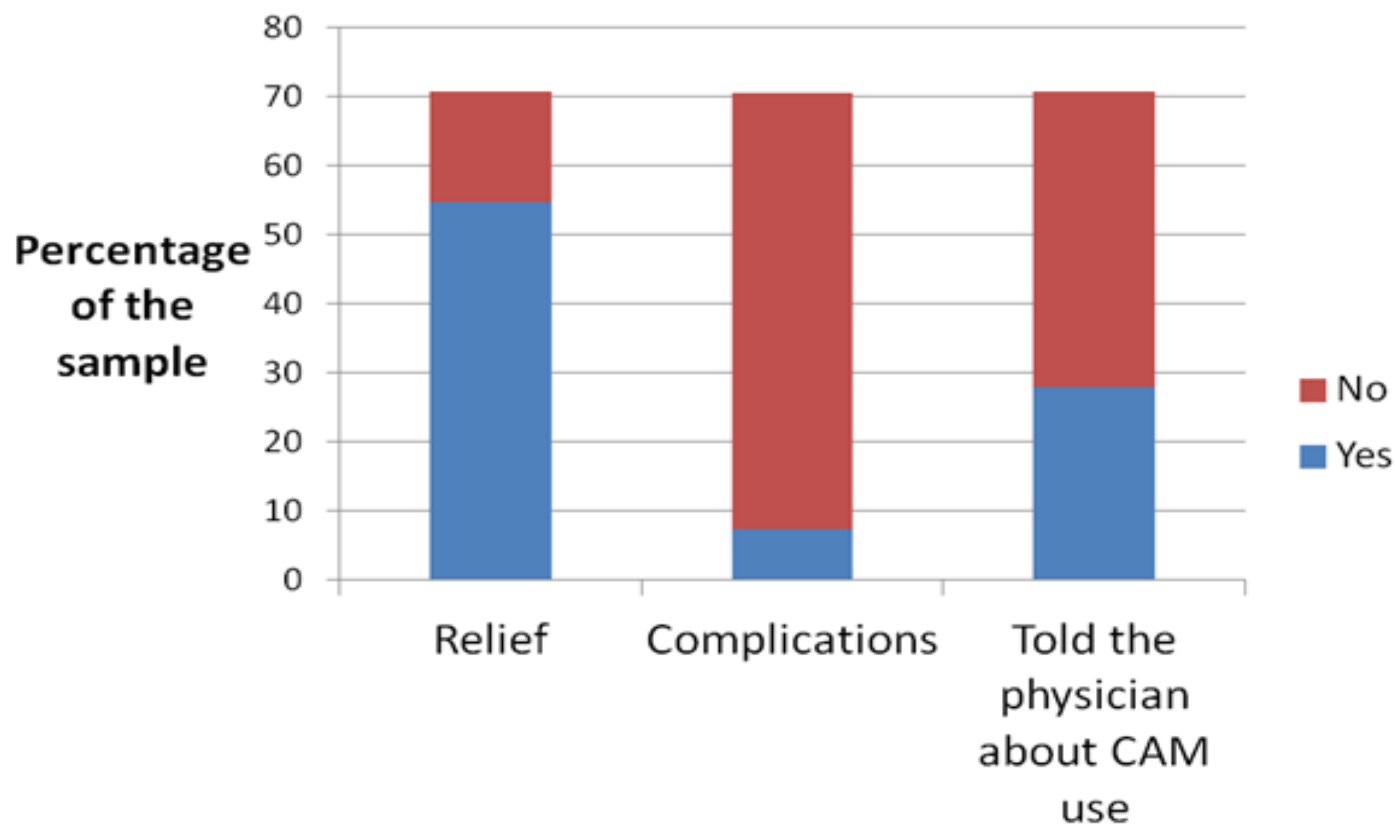

Figure 4: Consequences of using complementary and alternative medicine $(n=150)$ 


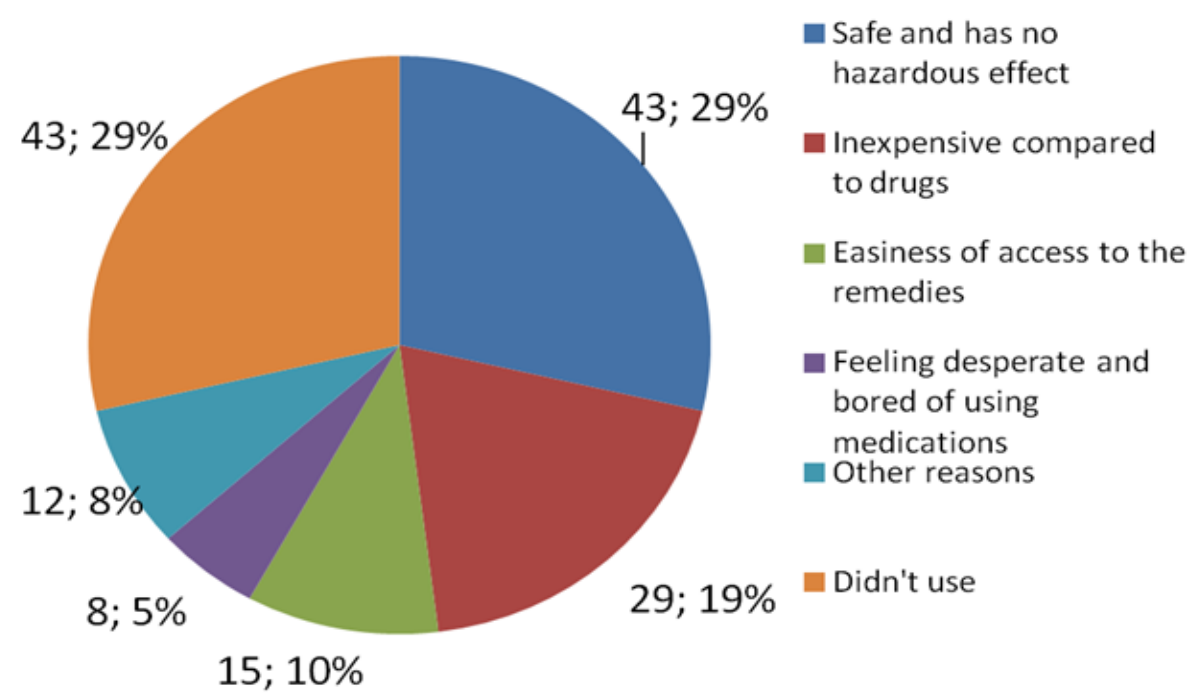

Figure 5: Reasons for using complementary and alternative medicine $(n=150)$ 


\section{تقييم معرفة و ممارسة و اعثقادات كبار السن للطب التكميلى و العربي الطب البديل المترددين على العيادات الخارجية للتأمين الصحى بالإسماعيلية}

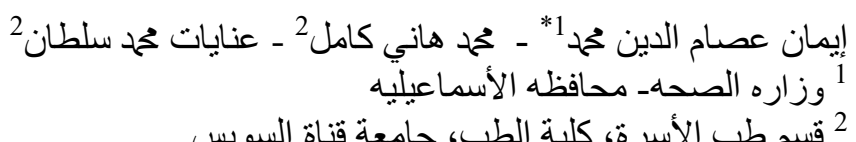
الخلفيه: تشير الدراسات الاستقصائية الأخيرة إلى أن كبار السن هم أكثر استخداما للأدوية التكميلية والبديلة. يمثل استخدامها في المسنين تحديات كبيرة. إن الوقاية من التفاعلات الضائرة و التفاعلات الدوائية المرتبطة باستخدام العلاج لتكميلى معقدة بسبب حقيقة أن أقل من 50٪ فقط من المرضى الأكبر سنًا يكثفون عن استخدامهم لهذا النوع من التداوى لاأطبائهم. و هذا هو السبب في أنه من الضروري لأطباء الأسرة استكثاف معارف وممارسات ومواقف المسنين تجاه العلاج التكميلى والبديل. الأهداف : تهدف الرسالة الى تقييم وعى وممارسة كبار السن للطب البديل و التكميلى و معتقداتهم تجاه هذا النوع من التدواى. و قد قامت هذه الدراسة على عينة 150 مريض من كبار السن المترددين على العيادات الخارجية بالتأمين الصحى بالإسماعيلية عن طريق استمارة استبيان. المنهجيه وطرق البحث: و تعتبر هذه الدراسة دراسة وصفية قائمة علي استمارة استبيان تتكون من أربعة أجز اء:

$$
\begin{aligned}
& \text { • الجزء الأول: بشمل البيانات الثخصية للمريض. }
\end{aligned}
$$

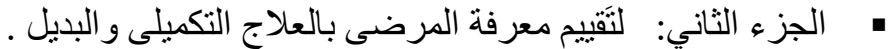

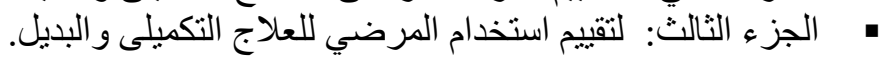

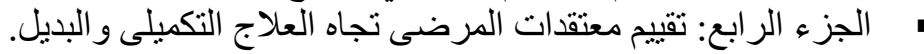

النتائج : اظهرت الدر اسه ان 84 \% على در اية بالطب البديل والتكميلى و أن 56\% من العينة يستقون معلوماتهم من وسائل الإعلام ثم الأسرة والأصدقاء. وكذلك اظهرت الدراسه ان 69.3\% سبق لهم استخدام الطب البديل و التكميلى حيث وجد ان استخدام الأعشاب هو الأكثر شيوعا (36.7\%) وأكثر الأعشاب استخداما هم الكركدية والنعناع و العرق سوس يليها استخدام الحجامة (15.3\%). وان نسبه 28\% فقط من العينة هم من أخبروا الأطباء باستخدامهر للطب البديل و التكميلى. كما اطهرت ان الغالبية( 63.3\%) لم يتعرضو الأى مضاعفات جر اء استخدامهم للطب البديل و التكميلى. أما بالنسبة لاعتقاداتهم تجاه استخدام الطب البديل والتكميلى 76\% يعتقدون أن التداوى بالطب البديل آمن وفعال بنسبة 58\% أما 70\% يرون أن استخدام الطب البديل بالإضافة إلى العلاج التقليدى. وان نسبه 50\% يعتقدون بأهمية إنشاء عيادات خاصة بالطب البديل والتكميلى بالمستشفيات والمراكز الطبية.

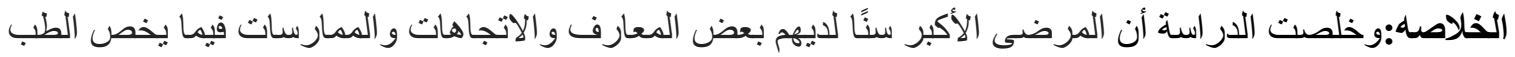
التكميلى و البديل و هذا يضع تبعه علي اطباء الأسره وهي ضروره التعرف علي ذلك خلال جلسات الاستشاره الطبيه

$$
\text { مع هذه الفئه من المرضى. }
$$

